\title{
THE INFLUENCE OF GOVERNANCE ON INTELLECTUAL CAPITAL IN TEXTILE INDUSTRY
}

\author{
Ramla Sadiq* \\ University of Management and Technology \\ Safia Nosheen \\ University of Management and Technology \\ Waseem Akhtar \\ South China University of Technology
}

\begin{abstract}
This study is aimed to evaluate the impact of corporate governance index on intellectual capital performance by developing the index from five sub-indices and incorporating the value-added intellectual coefficient (VAIC) methodology for intellectual capital performance. Fixed and Random Effect Regression techniques have been used to analyze the data of the textile sector in Pakistan from 2010 to 2014. The findings suggest a negatively significant impact of corporate governance index on intellectual capital performance while subindices give mixed results. The study also investigates the relationship of individual variables in each subindex with performance and results show a significant relationship for five variables namely independent director, independent audit committee, foreign shareholders ownership, gratuity, and remuneration committee. This study contributed empirical work in the literature of corporate governance and intellectual capital performance. The outcomes of this study can be used by policymakers as an attempt to boost the performance of the textile sector. A modified value-added intellectual coefficient (M-VAIC) methodology can be used in future research.
\end{abstract}

Keywords: Corporate governance; Intellectual capital performance; Related party transactions; Textile industry; Value added intellectual coefficient.

Received: 8 May 2019

Accepted: 9 September 2019

\section{INTRODUCTION}

Corporate governance is a set of rules, regulations, policies, and guidelines that provide a shield to investors, shareholders and other stakeholders against any fraudulent activities that can cause financial loss. According to Tariq and Butt (2008), it is referred to as a system and procedures in which the interest of all shareholders is protected, which provides directions to business matters to enhance the shareholders' value through good performance. A sound governance mechanism of

\footnotetext{
*Corresponding Author: RamlaSadiq, Department of Finance, School of Business and Economics, University of Management and Technology, C-II Johar Town, Lahore-54770, Pakistan; Email: ramla.sadiq@umt.edu.pk, ramlasadiq@gmail.com; Tel: +(92)334991-2642.
} 
corporations ensures the economic growth, the prosperity of shareholders, protection of investors, and safeguards the employment of workers.

From a global perspective, all countries have a different set of rules and regulations which make up the policies, guidelines or social norms according to their regional, social, political and religious requirements. These rules are published to ensure that all companies are obeying the same procedures to run their businesses (Black, Jang, \& Kim, 2003). Many countries have published their corporate governance codes and guidelines, and these are the binding regulations on the companies to protect all stakeholders' interests.

The interest of shareholders and executives may be dissimilar to each other as shareholders want wealth maximization whereas executives desire job security, high package with other fringe perquisites. This divergence of interest nurtures the principal-agent conflict. Countries with weak corporate governance systems face higher agency costs and their executives indulge in personal benefits instead of shareholder wealth maximization. To align the interest of executives with those of shareholders, the governance mechanisms (external and internal) play an important role. The external mechanism is made up of persons, institutions, labor market and stock market whereas internal mechanism comprises board size, composition, dual leadership, and ownership structure. The high proportion of managerial ownership encourages the management to make their concerns similar to those of stockholders.

The most recent study that incorporated a corporate governance index in Pakistan was Javaid and Saboor (2015) that constructed index from board, ownership and disclosure and conventional measures like ROA, ROE and Tobin Q is used to measure performance, Whereas the current study uses intellectual capital performance to measure performance and develops index from five subindices.

The success of business in the current era depends on knowledge and human resource, so conventional performance paradigm shifts into intellectual capital paradigm and researchers tries to investigate the relationship between governance attributes and intellectual capital performance elements (Shih, Chang, \& Lin, 2010). In Pakistan, Makki and Lodhi (2014) calculate intellectual capital efficiency through the value-added intellectual coefficient (VAIC) to find the relationship between corporate governance variables and performance. They find that corporate governance improves performance indirectly by exploiting the resources of intellectual capital. Therefore, this study is an effort to examine the relationship between corporate governance index and performance measured through intellectual capital value addition.

In Pakistan, there are few studies that incorporated corporate governance index to check its relationship with performance(Javaid \& Saboor, 2015). These studies use conventional measures for performance and some used intellectual capital performance but instead of the index, they incorporated only a few measures of corporate governance. Therefore, this study is an attempt to include corporate governance index and intellectual capital together to fill the gap considerably; further, the index includes the related party transaction dimension which is not commonly used due to the complex nature of data extraction from financial statements. The index, its subcomponents, and measurement are based on previous literature- specifically Black, et. al., (2012), Varshney, et.al., (2012). The specification of RPT in the gap is done so readers realize that RPTs are not commonly studied as their data is not readily available. 
The purpose of this study is to investigate the relationships between corporate governance variables and performance through VAIC methodology by constructing a corporate governance index from different dimensions of governance practices. Secondly, the study intends to determine the relationship of sub-indices of the corporate governance index with intellectual capital performance. Data from the companies of the Textile Industry listed on Pakistan Stock Exchange (former: Karachi Stock Exchange), all share index is analyzed to achieve the objectives by applying regression techniques.

This study would be useful for researchers, stakeholders of the company and policymakers and contribute to the literature of corporate governance index and intellectual capital performance. Researchers can use this study to support their future researches while stakeholders of the textile sector public listed companies can use the results to make business decisions e.g. investment decisions and strategies. The regulators and government bodies creating policies for the relevant textile companies may amend their policies and regulations e.g. compliance of audit practices ensures the transparent audit.

\subsection{Significance of Textile Sector}

According to Pakistan Economic Survey 2014-15, 20.30\% contribution in GDP is made by the industrial sector and $65.4 \%$ contribution is made in the industrial sector by sub-sector of manufacturing (Ministry of Finance, 2015a). The textile industry is the largest manufacturing sector in Pakistan that provides the largest employment opportunity for skilled, semi-skilled and unskilled labors. It adds an $8.5 \%$ share into GDP, above $60 \%$ contribution in export and over $40 \%$ workforce of manufacturing sector work in this sector(Ministry of Finance, 2015b). The textile industry comprises four key processes ginning, spinning, weaving and garments manufacturing.Irrespective of huge share in economy the textile industry continues to face various problems including volatile prices of cotton and yarn, lack of modern machinery, unreliable crop production, skilled labor deficiency and the most noticeable load shedding of gas and electricity.

\section{LITERATURE REVIEW AND HYPOTHESIS DEVELOPMENT}

Various research studies have been conducted in the area of corporate governance to show the link between governance index and performance in developed and developing countries. Most researchers find a positive relationship that better performance is associated with better governance.

\subsection{Corporate Governance and Conventional Measures}

Conventional measures (ROA, ROE, Tobin Q) had been mostly used to measure the performance of a company in the literature of corporate governance $(\mathrm{CG})$ to check the relationship of internal dynamics with performance (Makki\& Lodhi, 2013; Page, 2009).Page (2009) performed an investigation to check the link between corporate governance and performance variables in the UK by using data of 350 non-financial firms. Three performance variables were examined such as ROA, market to book ratio (Q) and sales to total assets ratio (SASET). Makki and Lodhi (2013) studied the relationship between corporate governance and performance in Pakistan by using the random sample from KSE all listed firms. They applied a partial least square (PLS) technique. 
They incorporated ownership structure, remuneration, CEO dual leadership and board structure for corporate governance while return on equity, return on investment and net profit after tax was measured for firm financial performance.

Some authors found positively significant relationships with conventional measures when they incorporate corporate governance index instead of taking individual dimensions of corporate governance (Balasubramanian, Black, \& Khanna, 2008; Gruszczynski, 2006; Hodgson, Lhaopadchan, \& Buakes, 2011; Renders, Gaeremynck, \& Sercu, 2010). Korent, Đunđek, and Calopa (2014) developed the Croatian Corporate Governance Index using annual questionnaires prepared by the Croatian Financial Services Supervisory Agency and Zagreb stock exchange. Positively significant findings had been concluded through simple and multiple regression techniques.

A research study was conducted to analyze the relationship between corporate governance index and market performance Tobin Q and accounting performance ROA and ROE by targeting the data of 58 companies from the manufacturing sector in Pakistan between 2009 and 2013. Through using 21 proxies for index and conventional measures for performance, Javaid and Saboor (2015) found a significant positive relationship between board structure and performance variables. The relationship of ownership structure was found strongly positive for ROA and ROE but not strong for Tobin Q while disclosure and transparency were significantly positively related to ROA but insignificant for ROE and Tobin Q.

A negative relationship was found in the studies of corporate governance index and firm performance (Ertugrul \& Hegde, 2009). The study examined the three ratings of governance namely governance metrics international (GMI), the corporate library (TCL) and institutional shareholder services (ISS) constructed by the leading rating agencies in the US and advocate a negative association between operating performance and ISS and TCL.

Many studies incorporated control variables to know the exact relationship between corporate governance and conventional measures e.g. Ab Razak, Ahmad, and Aliahmed (2008); Cheung, Thomas Connelly, Limpaphayom, and Zhou (2007). They used control variables like growth, size, non-duality, and leverage. Both studies identified a positive robust relationship between index and market value of firms which became stronger in the presence of control variables of performance.

Black, De Carvalho, and Gorga (2012) created a governance index to discover the relationship between the index and firm value calculated through Tobin's $Q$. They deduced a strong association between CG index and market value of small, high growth non-manufacturing firms but contrary to other studies, they found an inverse link between board independence and firm value. They argued that lower Tobin Q is expected through the better board independence.

Chiraz and Anis (2013) conducted a study on 139 French companies to find the relationship between corporate governance practices of Initial Public Offering (IPOs) firms and involuntary delisting from French stock exchanges. They applied a regression model to check the impact of governance practices such as independent directors, the board size, audit committee independence and CEO dual leadership on the dependent variable i.e. involuntary delisting. Results indicated that the delisted firms had weak corporate governance practices as compared to active firms on markets. 


\subsection{Corporate Governance and Value Added Intellectual Coefficient (VAIC)}

In the era of knowledge and intellectual capital in the corporate sector, the interest of researchers increases in the area of corporate governance with respect to value-added intellectual capital. Keenan and Aggestam (2001) debated on this topic conceptually whereas Ho and Williams (2003) examined it empirically. Firer and Williams (2003) states while comparing the VA and traditional measure of performance that knowledge is the key to future success but is not reflected in the traditional measure of performance. He also elaborates that traditional financial measure is just the driver of top management decision making that are not measuring the requirements of the modern companies. It is important to determine the extent to which such measures may intrinsically capture the contribution from intellectual capital resources such as human resources, customer reputation, and research and development. This is of particular importance in emerging economies that often have borrowed long-held financial models from developed economies, but are striving to strengthen their intellectual capital base to increase economic development. The researcher is in favor of the view that traditional measures of corporate performance may be unsuitable in the new economic world where competitive advantage is driven by intellectual capital.

A study was conducted to check the intellectual capital performance through a modified valueadded intellectual coefficient (M-VAIC) of the banking sector in Indonesia. Banks were categorized into four groups' i.e. top performers, good performers, common performers, and bad performers on the basis of scores given to M-VAIC performance. Three state-owned banks out of four came into category of top performers suggesting that the government-owned banks have the capability to compete with other banks and companies which negated the assumption that government banks faced difficulties for competition due to political pressure, poor image, high labor, social obligation, low performance and high bureaucracy(Ulum, Ghozali, \& Purwanto, 2014).

Existing studies do not discuss the individual impacts of governance mechanisms on VAIC; however, the assertion of existing research on individual subcomponents of governance on subcomponents of VAIC may be generalized as follows. Corporate governance can influence firm strategies from financial, investment, liquidity and compensation aspects. Essentially, firms may increase value through corporate governance mechanisms which can lead to effective financial policies in the form of capital structure decisions. These capital structure decisions contribute to structural capital in VAIC, as well as the value-added component of VAIC. Furthermore, when considering that financial strategies will affect the source and extent of debt utilization and its subsequent impact on financing cost, the impact in terms of structural capital changes on value addition will be more noticeable. Governance monitors the investment and liquidity decisions of the firm which would determine the positive projects that the firm may undertake and therefore add value by reducing underinvestment costs, increasing investment growth opportunities and liquidity. Corporate governance is responsible for the structure of the compensation structure that would determine whether managers are prone to more risk-taking behavior or not. This would allow us to determine the impact of the governance aspect on the human capital aspect of VAIC. Managers are risk-averse and as a result of their compensation and large stock holding, managers would avoid investing in riskier long term projects even with high returns, to the detriment of shareholders. This is significant to note as it indicates that ownership structures, a subcomponent of corporate governance, directly influences value addition in the organization. 
Varshney, Kaul, and Vasal (2012) investigated the linkage between CG index and firm performance by using conventional as well as economic value added (EVA) measures. They incorporated a sample of 105 companies from India. They observed a significant link between index and performance when performance was measured through EVA but found no relationship for conventional measures ROCE and Tobin's Q.

In Pakistan, the data of the banking sector was analyzed by applying regression to determine intellectual capital performance through the VAIC technique (Bharathi, 2010). The findings of the study suggested that the banks in the private sector were performing well as compared to other banks that showed efficient management and usage of human resources. Another study in the Pakistani banking sector Sabir, Arshad, Sardar, and Latif (2014) also observed the same results for private banks whereas no relationship for government banks and productivity calculated via asset turnover ratio.

In the context of Pakistan corporate sector, the Hypothesis formulated to test the impact of CG on IC performance;

Hypothesis 1: There is a positive significant impact of the CG Index on IC performance.

In a study to explore the impact of governance provisions on intellectual capital disclosure by taking the sample of biotechnology firms from European countries, the results identified positive relationship of independent directors and negative of dual leadership, board structure and size with voluntary disclosure of intellectual capital comprising of both financial and non-financial information(Cerbioni\& Parbonetti, 2007).

Some researchers found no relationship between corporate governance variables and intellectual capital e.g. Taliyang and Jusop (2011) used three sets relational capital, structural capital and human capital to measurer IC disclosure and four variables of CG in Malaysia by handling the sample of 150 firms from five industries whereas Abdoli, Panahi, and Rahimiyan (2013) incorporated the data of automakers corporations registered in Tehran Stock Exchange.

The research studies, conducted by taking a sample of seventy-five firms quoted on Bursa Malaysia, seventy-four banks listed on the Arab Gulf Cooperation Council and all listed companies in KSE Pakistan used VAIC methodology to examine the association between corporate governance and intellectual capital performance. The researchers obtained remarkable results that gave a robust connection of board size, composition, independence, family and institutional ownerships with the performance of intellectual capital but found no impact of dual leadership and director's ownership with performance. They proposed that good governance tools enhance performance by improving intellectual capital efficiency (Abidin, Kamal, \& Jusoff, 2009; AlMusalli\&Ismail, 2012; Makki\& Lodhi, 2014).

As the objective of the study is to determine the relationship of sub-indices of corporate governance index with intellectual capital performance in the context of the Pakistan corporate sector following sub Hypothesis are formulated, Hypothesis 2a: There is a positive significant impact of the sub-index board structure on IC performance.

Hypothesis $2 \mathrm{~b}$ : There is a positive significant impact of the sub-index ownership structure on IC performance. 
Hypothesis 2c: There is a positive significant impact of the sub-index disclosure on IC performance.

Hypothesis 2d: There is a positive significant impact of the sub-index related parties' transactions on IC performance.

Hypothesis 2e: There is a positive significant impact of the sub-index remuneration on IC performance.

\section{METHODOLOGY}

\subsection{Research Design}

This research study is a correlational quantitative study in which the relationship between the corporate governance index and firm intellectual capital performance is evaluated.

Figure 1: Conceptual Model

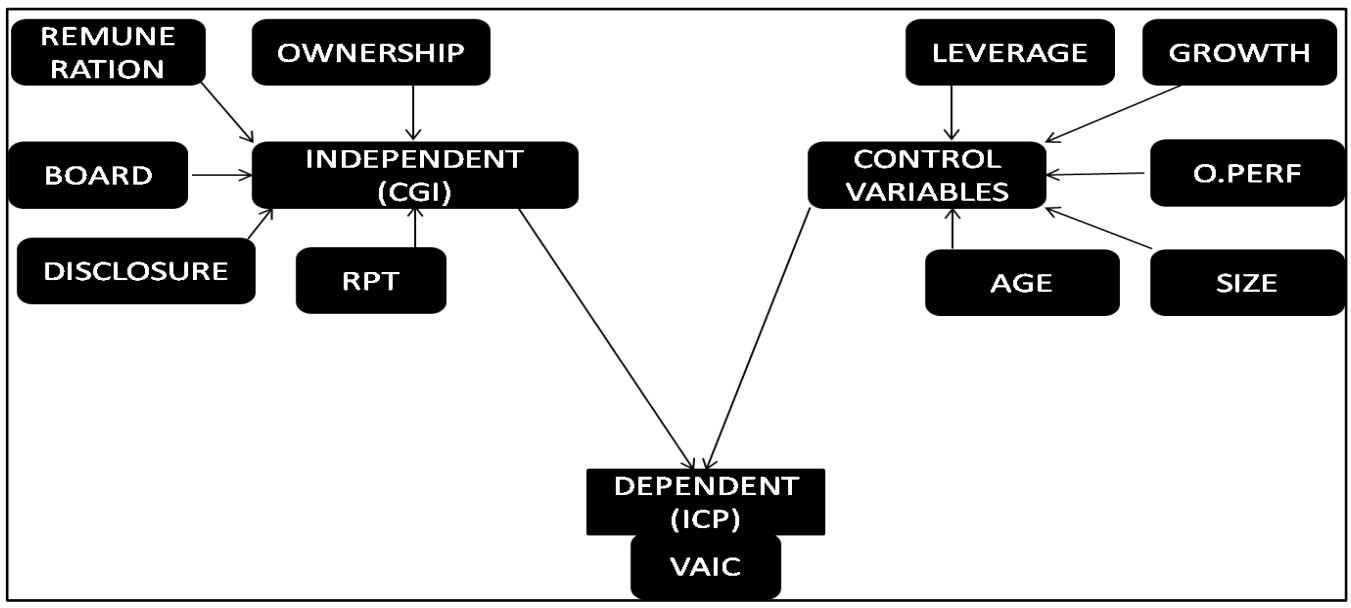

\section{2. $\quad$ Sample and Data Collection}

The companies of the Textile Industry listed in Pakistan Stock Exchange (All Share Index) are used to analyze the relationship between CG and performance. Table 1 shows the population, sample and final sample with respect to each sub-sector in the textile sector.

Table 1: Sample Selection

\begin{tabular}{lll}
\hline \hline Sector & Population & Sample \\
\hline Jute & 3 & - \\
Synthetic & 11 & 6 \\
Composite & 56 & 22 \\
\hline
\end{tabular}




\begin{tabular}{lll}
\hline \hline Sector & Population & Sample \\
\hline Spinning & 86 & 39 \\
Weaving & 14 & 6 \\
Woolen & 2 & 1 \\
Total & 172 & 74 \\
Not available & & 12 \\
\hline \hline
\end{tabular}

A systematic sampling technique is used to get the sample that represents fifty percent of its population. The value of the total assets (size-based classification) is used to classify these companies into two groups. The group above the median is named large companies ( 86 companies) whereas below the median is small companies (86 companies) according to size-based classification. Secondary data is extracted from annual reports of companies. The comprehensive nature of the calculation of the composite CG index and VAIC limited the authors to analyze the data of five years, from 2010 to 2014 . The data of 12 companies are not available; therefore the final sample for analysis consists of 74 companies.

\subsection{Measurement of Variables}

Corporate Governance Index is used to measure the various aspects of corporate governance through five sub-indices, whereas intellectual capital through value-added intellectual coefficient (VAIC) (Pulic, 1998) methodology is used to analyze the performance aspect. Corporate governance comprises five sub-indices i.e. board structures, ownership structure, disclosure, related party transactions, and remunerations. The score is assigned to each variable according to the method used in prior studies(Black et al., 2012; Varshney et al., 2012). Table 2 shows the measurement of each variable.

Table 2: Measurement of Variables

\begin{tabular}{lll}
\hline \hline Name & Measurement & Score \\
\hline $\begin{array}{l}\text { Corporate Governance Index } \\
\text { Sub-Index: Board structure }\end{array}$ & & \\
BS1-Board size & Number of directors on board & $0-1$ \\
BS2-One or more independent & Whether the board includes one or more independent & $1 / 0$ \\
directors & directors or not & \\
BS3-30\% independent directors & Whether the board includes 30\% independent & $1 / 0$ \\
& directors or not & \\
BS4-CEO dual leadership & Whether the CEO is also the chairman of the board or & $1 / 0$ \\
& not & $1 / 0$ \\
BS5-Board meetings & Whether more than 4 board meetings held during a & $1 / 0$ \\
BS6-Audit committee & year or not & $1 / 0$ \\
BS7-Audit committee independence & Whether more than 3 members exist in the audit & \\
& Committee or not & $1 / 0$ \\
BS8-CFO existence & independent director or not & \\
\hline
\end{tabular}




\begin{tabular}{|c|c|c|}
\hline Name & Measurement & Score \\
\hline \multicolumn{3}{|l|}{ Sub Index: Ownership Structure } \\
\hline OS1-Individual large shareholders & $\begin{array}{l}\text { The proportion of ordinary shares held by individual } \\
\text { shareholders }\end{array}$ & $0-1$ \\
\hline OS2-Block-holder ownership & $\begin{array}{l}\text { The proportion of shareholders holding more than } 5 \% \\
\text { shares }\end{array}$ & $0-1$ \\
\hline OS3-Institutional ownership & $\begin{array}{l}\text { The proportion of shares held by institutional } \\
\text { investors }\end{array}$ & $0-1$ \\
\hline OS4-Managerial ownership & $\begin{array}{l}\text { The proportion of shares held by directors, } \\
\text { executives, and relatives }\end{array}$ & $0-1$ \\
\hline OS5-Associated ownership & $\begin{array}{l}\text { The proportion of shares held by associated } \\
\text { companies and undertaking }\end{array}$ & $0-1$ \\
\hline OS6-Govt. ownership & The proportion of shares held by the government & $0-1$ \\
\hline OS7-Foreign ownership & The proportion of shares held by foreign investors & $0-1$ \\
\hline \multicolumn{3}{|l|}{$\begin{array}{l}\text { Sub Index: Disclosure and } \\
\text { Transparency }\end{array}$} \\
\hline DT1-Disclosure of CG practices & $\begin{array}{l}\text { Whether the company has prepared a code of conduct } \\
\text { or not }\end{array}$ & $1 / 0$ \\
\hline DT2-Disclosure of remuneration & $\begin{array}{l}\text { Whether the company has disclosed remuneration or } \\
\text { not }\end{array}$ & $1 / 0$ \\
\hline $\begin{array}{l}\text { DT3-Disclosure of shareholding } \\
\text { categories }\end{array}$ & $\begin{array}{l}\text { Whether the company has disclosed shareholding } \\
\text { categories or not }\end{array}$ & $1 / 0$ \\
\hline $\begin{array}{l}\text { DT4-Disclosure of executive } \\
\text { member's ownership }\end{array}$ & $\begin{array}{l}\text { Whether the company has disclosed executive } \\
\text { ownership or not }\end{array}$ & $1 / 0$ \\
\hline $\begin{array}{l}\text { DT5-Disclosure of related party } \\
\text { transactions }\end{array}$ & $\begin{array}{l}\text { Whether the company has disclosed related parties } \\
\text { transactions }\end{array}$ & $1 / 0$ \\
\hline $\begin{array}{l}\text { DT6-Five years availability of } \\
\text { annual reports }\end{array}$ & $\begin{array}{l}\text { Whether five years of annual reports available on the } \\
\text { company website or not }\end{array}$ & $1 / 0$ \\
\hline \multicolumn{3}{|l|}{ Sub Index: Related Party Transactions } \\
\hline RPT1-Loan to or from RP members & Whether a loan transaction has been done or not & $1 / 0$ \\
\hline $\begin{array}{l}\text { RPT2-Sale to or purchase from RP } \\
\text { members }\end{array}$ & $\begin{array}{l}\text { Whether sale and purchase transactions have been done or } \\
\text { not }\end{array}$ & $1 / 0$ \\
\hline $\begin{array}{l}\text { RPT3-Rent real property to or from RP } \\
\text { members }\end{array}$ & $\begin{array}{l}\text { Whether rental real property transaction has been done or } \\
\text { not }\end{array}$ & $1 / 0$ \\
\hline $\begin{array}{l}\text { RPT4-Dividend paid to or received from } \\
\text { RP members }\end{array}$ & Whether dividend transaction has been done or not & $1 / 0$ \\
\hline $\begin{array}{l}\text { RPT5-Donation paid to or received from } \\
\text { RP members }\end{array}$ & Whether a donation transaction has been done or not & $1 / 0$ \\
\hline $\begin{array}{l}\text { RPT6-Insurance paid to or claimed from } \\
\text { RP members }\end{array}$ & Whether an insurance transaction has been done or not & $1 / 0$ \\
\hline $\begin{array}{l}\text { RPT7-Interest paid to or received from } \\
\text { RP members }\end{array}$ & Whether interest transaction has been done or not & $1 / 0$ \\
\hline $\begin{array}{l}\text { RPT8-Bonus share allotted to or received } \\
\text { from RP members }\end{array}$ & Whether a bonus shares transaction has been done or not & $1 / 0$ \\
\hline $\begin{array}{l}\text { RPT9-Contribution made in gratuity and } \\
\text { provident fund } \\
\text { Sub Index: Remuneration }\end{array}$ & $\begin{array}{l}\text { Whether contribution in gratuity and provident fund } \\
\text { transaction has been done or not }\end{array}$ & $1 / 0$ \\
\hline
\end{tabular}




\begin{tabular}{lll}
\hline \hline Name & Measurement & Score \\
\hline R1-Remuneration committee & Whether more than 3 members exist in the remuneration & $1 / 0$ \\
& committee or not & \\
R2-Remuneration committee & Whether remuneration committee includes one independent & $1 / 0$ \\
independence & director or not & \\
R3-CEO remuneration & Whether remuneration is given to CEO or not & $1 / 0$ \\
R4-Directors remuneration & Whether remuneration is given to directors or not & $1 / 0$ \\
R5-Executive remuneration & Whether remuneration is given to executives or not & $1 / 0$ \\
R6-Cash-based remuneration & Whether compensation is paid to the CEO, directors, and & $1 / 0$ \\
& executives in cash form or not & \\
Intellectual Capital Performance & & Value \\
Value added intellectual coefficient & VAIC= CEE+ HCE+ SCE & Ratio \\
Control Variables & & Value \\
Operating Performance & EBIT to total assets & Ratio \\
Firm size & Total assets and total sales of the company & Ratio \\
Leverage & Total debt to total assets ratio & Value \\
Growth & Percentage change in sales \\
Firm age & Year of registration in SECP to the year 2014 & \\
\hline \hline
\end{tabular}

Notes: The score is assigned to board size in the following manner (Varshney et al., 2012).

If board size $\leq 5$ then score will be 0.50

If board size $=6$ or 7 then score will be 0.65

If board size $=8$ or 9 then score will be 0.80

If board size $=10$ or 11 then score will be 1.00

If board size $=12$ or 13 then score will be 0.95

If board size $\geq 14$ then score will be 0.90

The scores obtained by each variable is either a proportion value ranging from 0 to 1 or an absolute value of 0 or 1 . Equal weight has been allotted to each variable in the sub-index to make an equal-weighted sub-index so a total score in each subindex is divided by the total number of variables in that sub-index. To get an equal-weighted corporate governance index, the aggregate score obtained from the addition of each sub-index score is divided by 5 (five sub-indexes).

\subsection{Intellectual Capital Performance}

Intellectual capital performance is measured through the value-added intellectual capital coefficient (VAIC) method introduced byPulic (1998). The method was designed to incorporate value formation information of both tangible and intangible resources of companies. Pulic (2004) specified that two resources namely capital employed and intellectual capital (human and structural capital) add value to business entities. Al-Musalli and Ismail (2012); Ho and Williams (2003); Ismail and Karem (2011) incorporated this mechanism in their studies to compute the performance of intellectual capital. The formula of VAIC is written in the following manner;

Whereas,

$$
\mathrm{VAIC}=\mathrm{CEE}+\mathrm{HCE}+\mathrm{SCE}
$$

$\mathrm{CEE}=$ Capital Employed Efficiency (VA/CE)

$\mathrm{HCE}=$ Human Capital Efficiency $(\mathrm{VA} / \mathrm{HC})$

$\mathrm{SCE}=$ Structural Capital Efficiency (SC/VA)

VA $=$ Value Added (Operating Profit (EBIT) + Employee Cost + Depreciation + Amortization) 
EBIT $=$ Earnings before Interest and Tax

$\mathrm{CE}=$ Capital Employed (Total Assets - Current Liabilities)

$\mathrm{HC}=$ Human Capital (Total Wages and Salaries of the Firm)

$\mathrm{SC}=$ Structural Capital (Value added - Human Capital)

\section{Analytical Procedures}

This study is applying descriptive statistics, correlational matrix and multiple regression techniques as used byAbidin et al. (2009); Korent et al. (2014) to figure out the relationship between corporate governance index and intellectual capital performance. Six equations are formulated to check the relations of $\mathrm{CG}$ index and sub-indices with intellectual capital performance (ICP) measured through VAIC.
$\mathrm{VAIC}=\alpha+\beta_{1} \mathrm{CGI}+\beta_{2} \mathrm{CONVAR}+\varepsilon$
$\mathrm{VAIC}=\alpha+\beta_{1} \mathrm{BOARD}+\beta_{2} \mathrm{CONVAR}+\varepsilon$
$\mathrm{VAIC}=\alpha+\beta_{1} \mathrm{OWNER}+\beta_{2} \mathrm{CONVAR}+\varepsilon$
$\mathrm{VAIC}=\alpha+\beta_{1} \mathrm{DISCL}+\beta_{2} \mathrm{CONVAR}+\varepsilon$
$\mathrm{VAIC}=\alpha+\beta_{1} \mathrm{RPT}+\beta_{2} \mathrm{CONVAR}+\varepsilon$
$\mathrm{VAIC}=\alpha+\beta_{1} \mathrm{REMUN}+\beta_{2} \mathrm{CONVAR}+\varepsilon$
Whereas,
VAIC $=$ Value Added Intellectual Coefficient
$\mathrm{CGI}=$ Corporate Governance Index
$\mathrm{BOARD}=$ sub-index board structure
OWNER $=$ sub-index ownership structure
$\mathrm{DISCL}=$ sub-index disclosure and transparency
$\mathrm{RPT}=$ sub-index related party transactions
REMUN= sub-index remuneration
CONVAR $=$ control variables
$\alpha=$ intercept
$\beta=$ coefficient
$\mathcal{E}=$ error term

\section{RESULTS AND DISCUSSION}

\subsection{Descriptive Statistics}

Table 3 provides the descriptive of main variables.

Table 3: Descriptive Statistics

\begin{tabular}{lllll}
\hline \hline Variable & Observations & Mean & Minimum & Maximum \\
\hline VAIC & 312 & 3.417 & -7.74 & 15.35 \\
CGI & 345 & 0.420 & 0 & 0.68 \\
SIB & 312 & 0.501 & 0.1 & 0.85 \\
SIOWN & 295 & 0.214 & 0.04 & 0.4 \\
SIDIS & 300 & 0.938 & 0.67 & 1 \\
SIRPT & 343 & 0.006 & 0 & 0.06 \\
SIREM & 312 & 0.682 & 0 & 1 \\
EBITTA & 320 & 0.093 & -0.44 & 0.7 \\
\hline \hline
\end{tabular}




\begin{tabular}{lllll}
\hline \hline Variable & Observations & Mean & Minimum & Maximum \\
\hline TA & 322 & 22.064 & 15.19 & 25.3 \\
TS & 343 & 22.167 & 14.86 & 24.72 \\
GROW & 326 & 0.216 & -0.97 & 9.41 \\
DAR & 316 & 0.601 & 0.15 & 9.19 \\
AGE & 370 & 31.75 & 7 & 64 \\
\hline \hline
\end{tabular}

\subsection{Fixed and Random Effect Models}

Hausman test has been carried out to find the best technique(Random or fixed) for each model(Gujarati, 2009). The summary is given in Table 4.

Table 4: Fixed and Random Effect Models

\begin{tabular}{lllll}
\hline \hline Model/Hypotheses & Fixed Effect & $\begin{array}{l}\text { Random } \\
\text { Effect }\end{array}$ & Hausman Test & Selection \\
\hline 1. CGI & $-3.39^{*}$ & -1.25 & $\mathrm{Chi}^{2}=11.17^{*}$ & Fixed Effect \\
2a.SIB & $1.27^{*}$ & $1.13^{\dagger}$ & $\mathrm{Chi}^{2}=-110.32$ & Random Effect \\
2b.SIOWN & -2.56 & -0.65 & $\mathrm{Chi}^{2}=21.86^{* *}$ & Fixed Effect \\
2c.SIDIS & 0.39 & 1.44 & $\mathrm{Chi}^{2}=22.19^{* *}$ & Fixed Effect \\
2d.SIRPT & -14.05 & $-21.97^{\dagger}$ & $\mathrm{Chi}^{2}=7.37$ & Random Effect \\
2e.SIREM & $-1.27^{\dagger}$ & $-1.27^{*}$ & $\mathrm{Chi}^{2}=1.12$ & Random Effect \\
\hline \hline
\end{tabular}

Notes: $\dagger \mathrm{p}<0.10 ;{ }^{*} \mathrm{p}<0.05 ; * * \mathrm{p}<0.01 ; * * \mathrm{p}<0.001$

CGI (corporate governance index), SIB (sub-index board), SIOWN (sub-index ownership), SIDIS (sub-index disclosure), SIRPT (sub-index related parties' transactions) and SIREM (sub-index remuneration) are independent variables.Chi ${ }^{2}$ represents the value of chi-squared in the Hausman test. It shows that the fixed effect technique is best for three models CGI, SIOWN and SIDIS whereas the random effect technique is best for the other three models SIB, SIRPT and SIREM.

\subsection{Correlation Matrix}

Table 5 shows the correlation between variables. The results show that no multicollinearity exists between the independent variables.

Table 6 depicts the summarized results of hypothesis and sub-hypotheses by using fixed-effect or random effect regression techniques. It also shows the autocorrelation and heteroskedasticity in the model. 


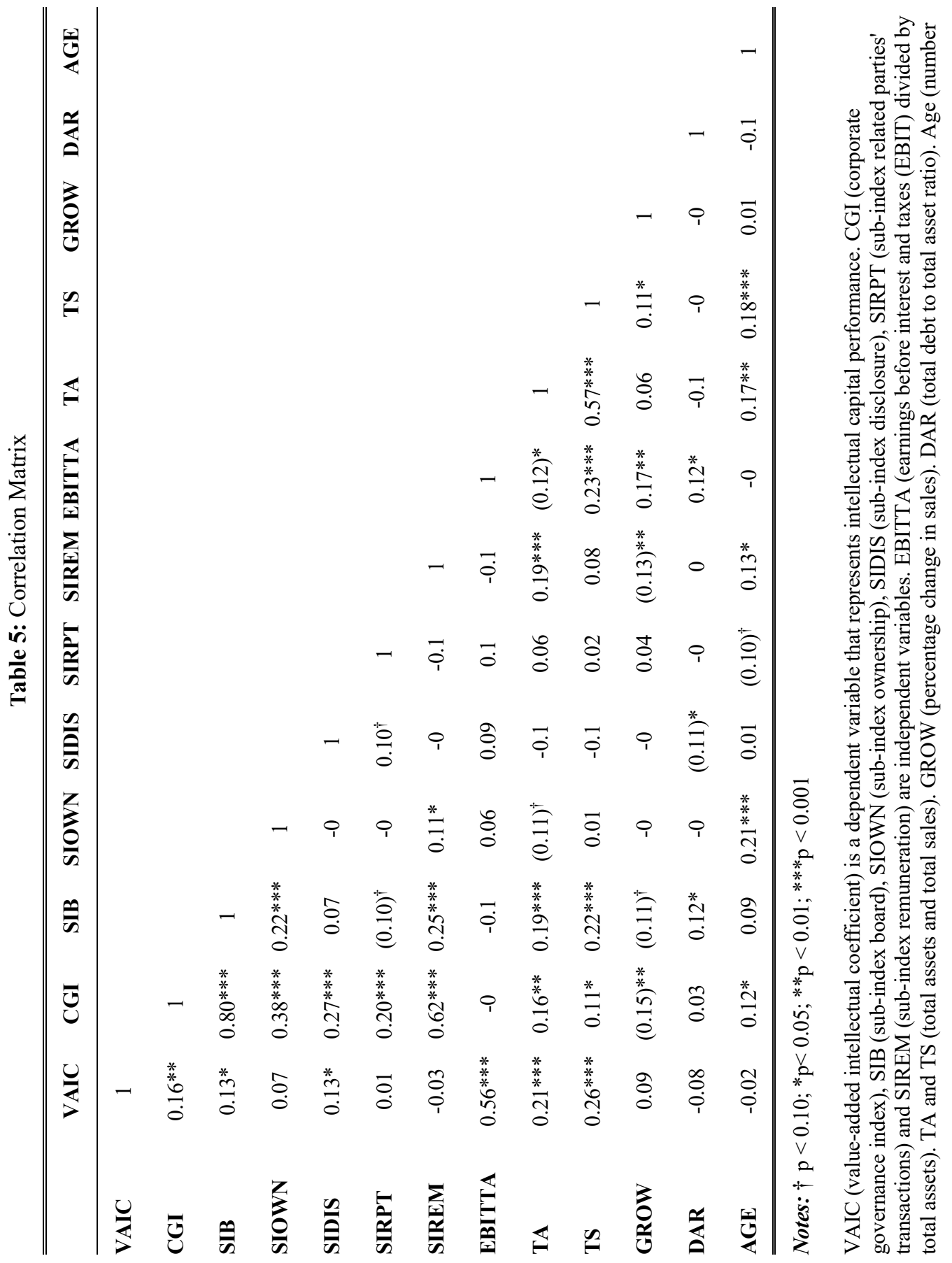




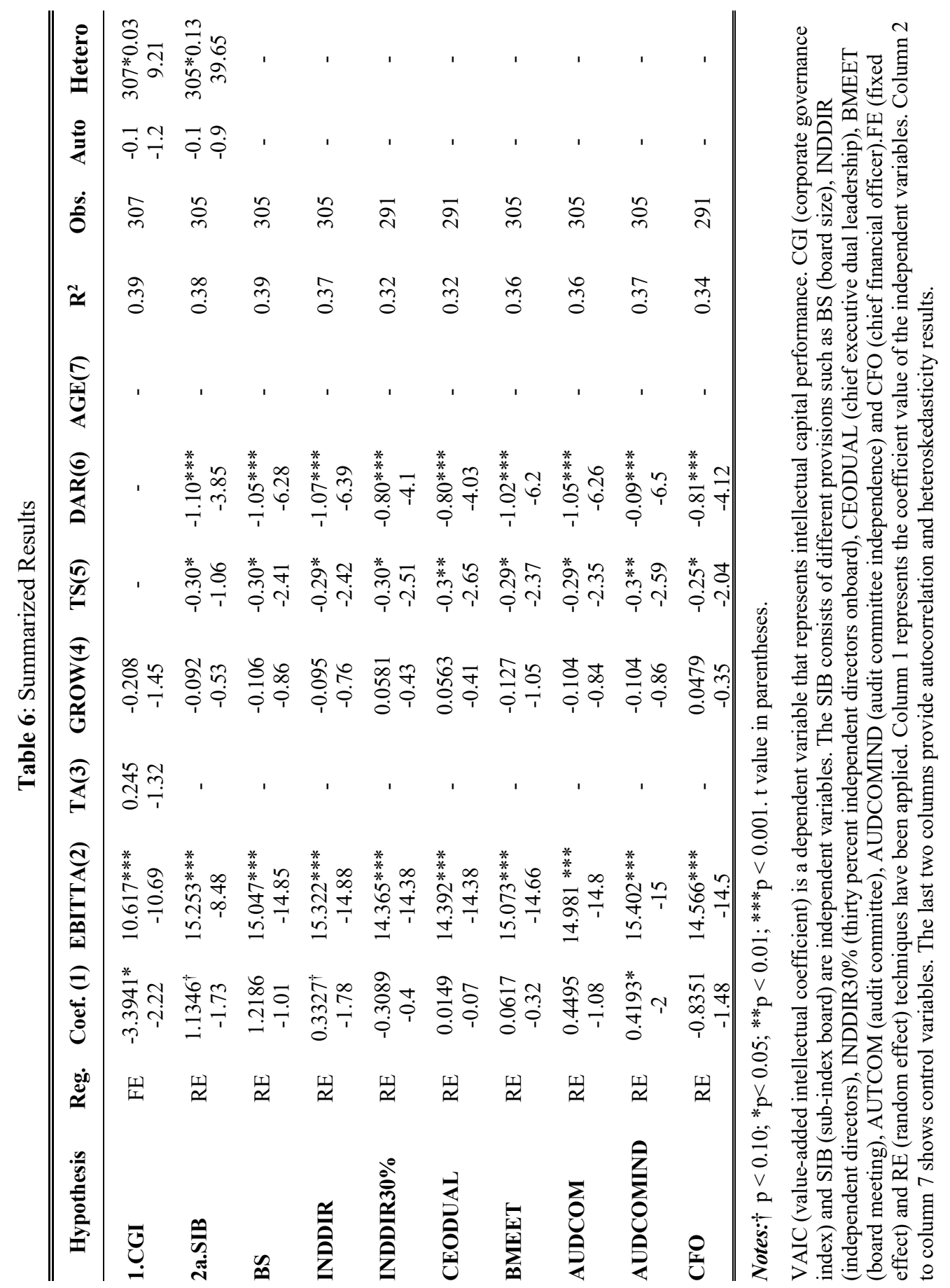


Ramla Sadiq, Safia Nosheen, Waseem Akhtar

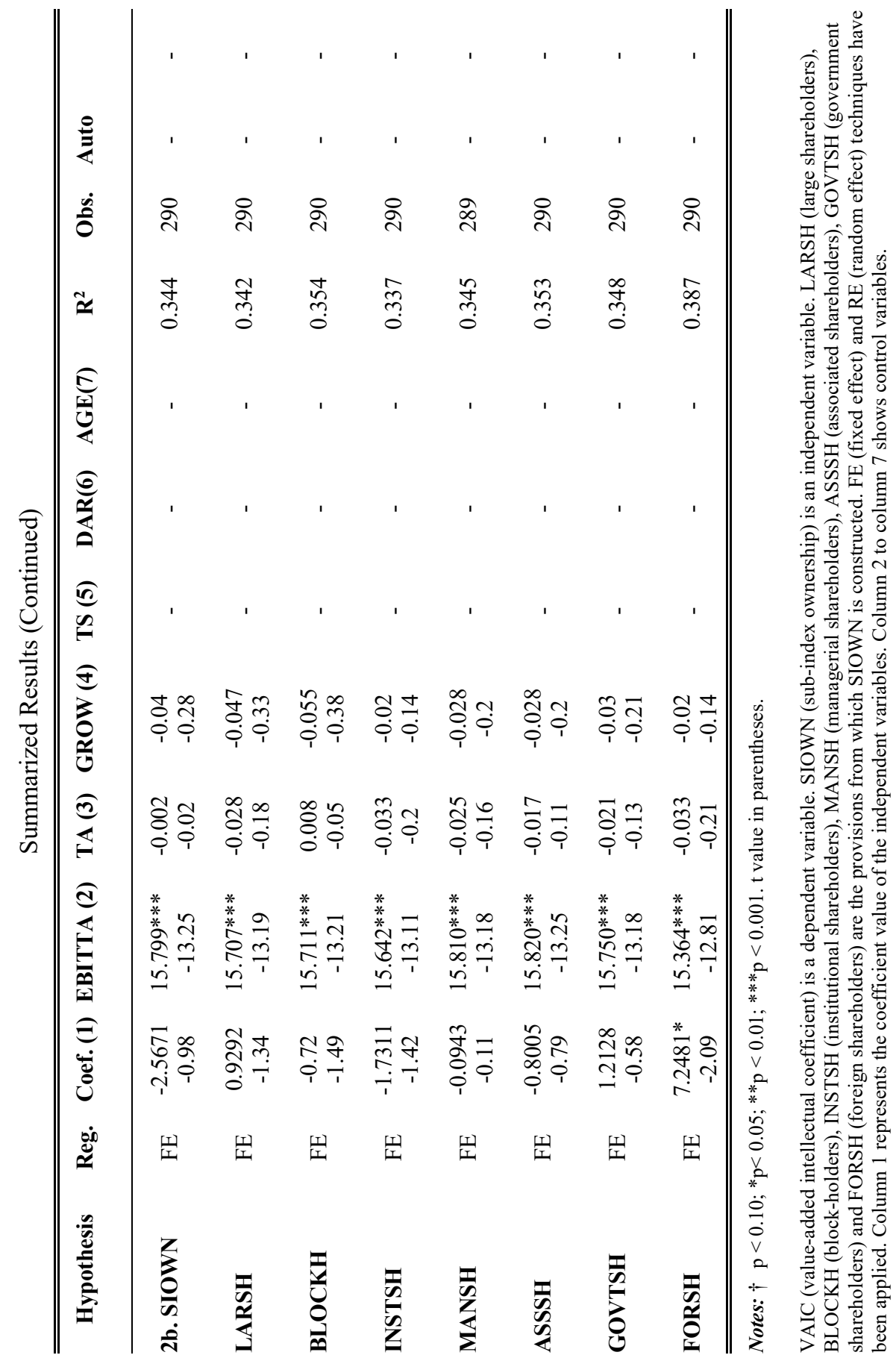




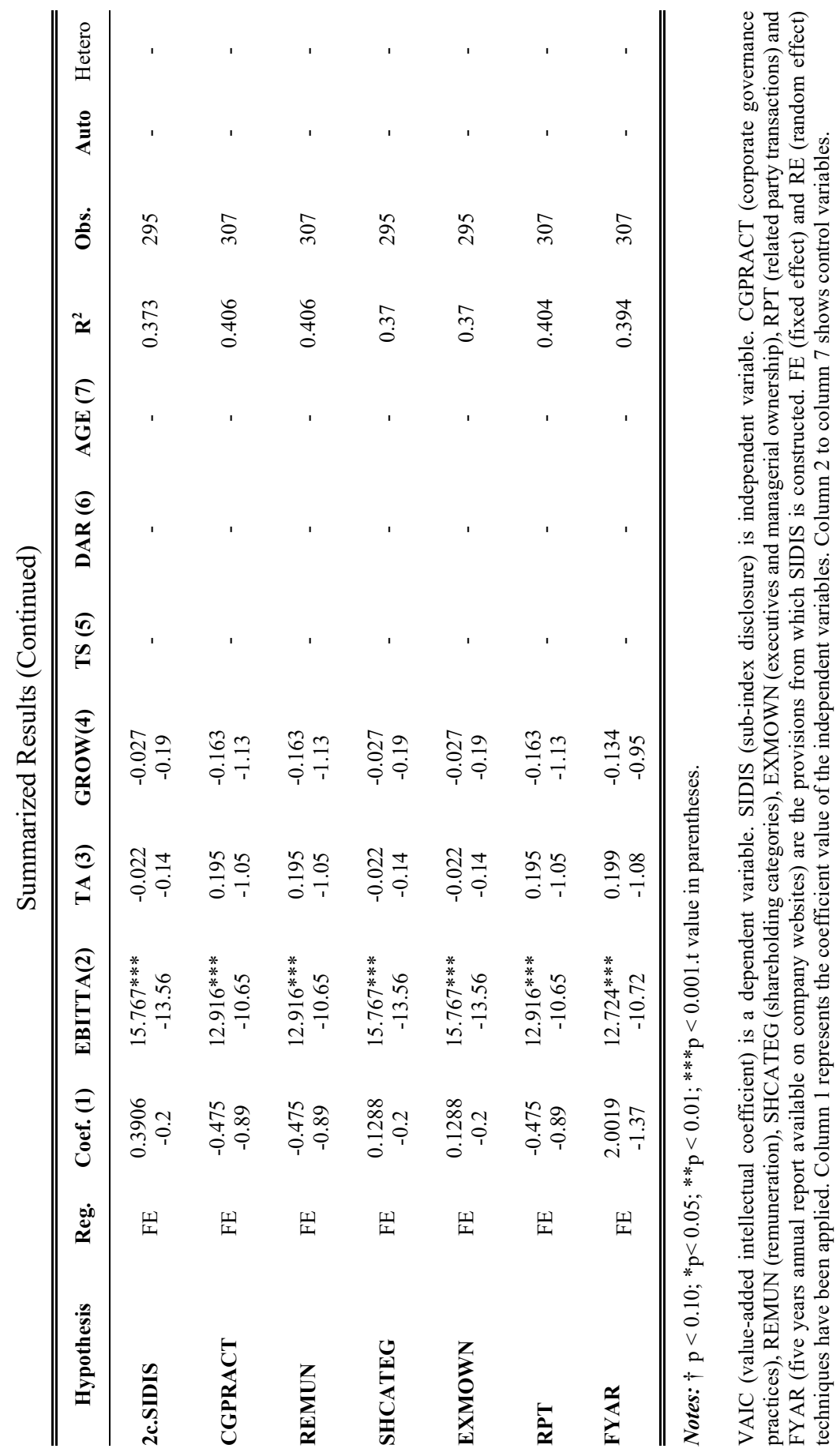


Ramla Sadiq, Safia Nosheen, Waseem Akhtar

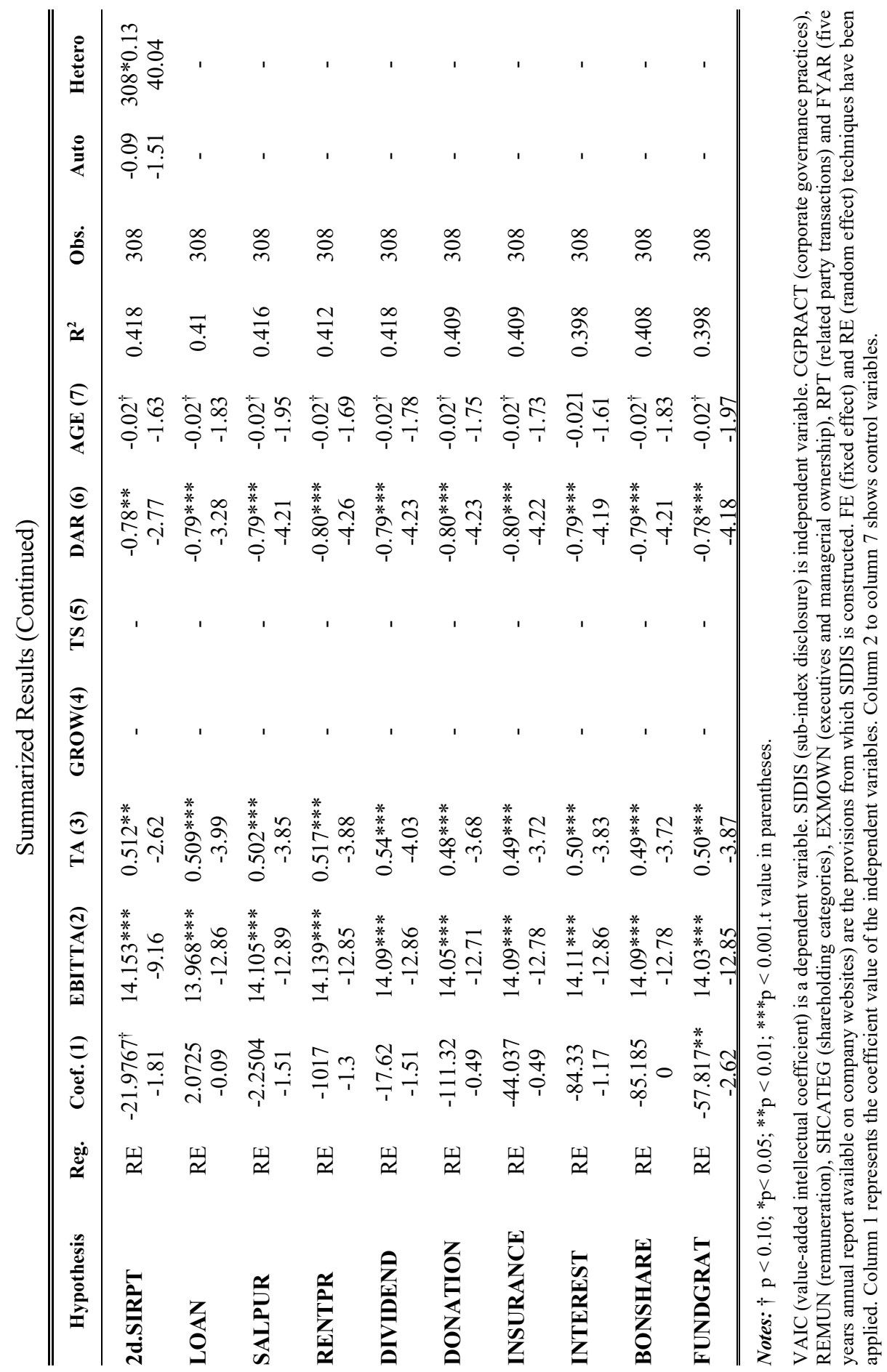




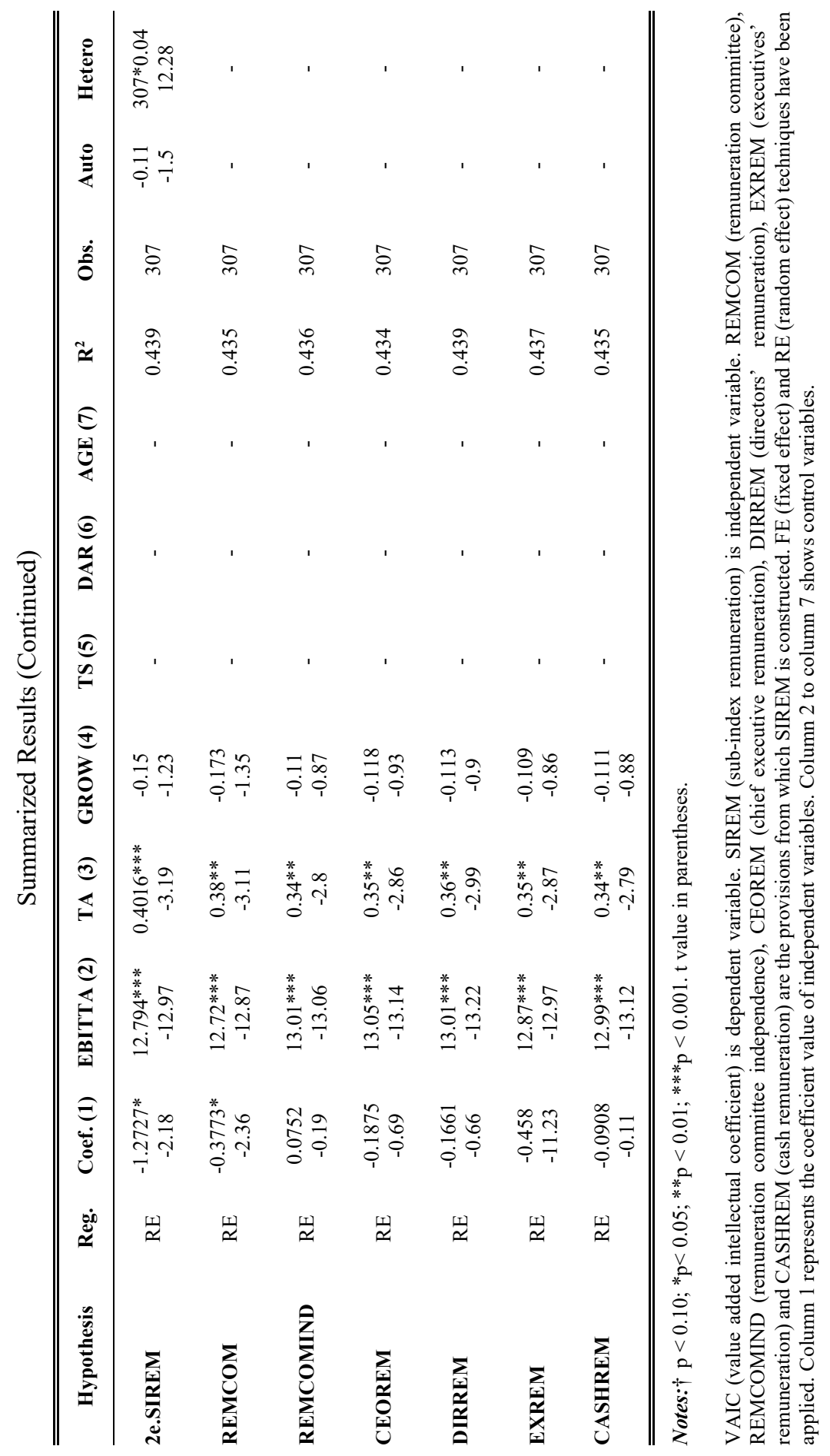


The results shown in table 6 depicts that there is a significant negative impact of corporate governance index on intellectual capital performance (VAIC)which accepts the alternative hypothesis 1 and it is confirmed by the previous study ((Bebchuk, Cohen, \& Ferrell, 2004); Ertugrul \& Hegde, 2009).

Some authors such as Korent et al. (2014); Varshney et al. (2012) found significant positive relationship whereas Varshney et al. (2012) found negative but insignificant relationship between CGI and performance when measured through traditional measures like return on net worth (RONW), return on capital employed(ROCE) and Tobin Q. The relationship of control variables operating performance (EBITTA) is positive significant with VAIC that is consistent with the previous study of Black (2005).

The association of sub-index board (hypothesis 2a) is positively significant with performance (VAIC) consistent with the study of Abidin et al. (2009); Javaid and Saboor (2015), sub-index ownership (hypothesis 2b) gives insignificant impact on IC performance supported by the study of Abidin et al. (2009) and sub-index disclosure (hypothesis 2c) provides positive but insignificant impact on dependent variable confirmed by the study of Javaid and Saboor (2015). There is a significant negative impact of sub-index RPT (hypothesis 2d) on IC performance. Results are steady with the studies of Black (2005); Black et al. (2012). The impact of sub-index remuneration (hypothesis 2e) on intellectual capital performance is also negative significant constant with studies of Brick, Palmon, and Wald (2006); Usman, Akhter, and Akhtar (2015).

Variables such as independent director (INDDIR), audit committee independence (AUDCOMIND) and foreign shareholder (FORSH) have a positive significant relationship with intellectual capital performance. Two variables fund and gratuity (FUNDGRAT) and remuneration committee (REMCOM) have a significant negative link with intellectual capital performance while no provision is significant in the sub-index disclosure.

The autocorrelation and heteroskedasticity tests have been applied on four hypotheses out of six hypotheses which are significant. There is no autocorrelation in these four models because values are insignificant. The robust test has been applied to overcome the hetero problem for SIB and SIRPT. The values given in table 6 for these two hypotheses are taken from the robust tests.

\section{Sub-sectors in Textile Industries}

The selected data covers the five sub-sectors (synthetic, composite, spinning, weaving and woolen) out of six sub-sectors in the textile industry. The data of one sub-sector (jute) could not come in the sample due to the systematic sampling technique that was incorporated in this study. Each hypothesis of the study is also tested with respect to each sub-sector. The results of six hypotheses regarding each sub-sector are provided in Table 7. 
Table 7: Sub-Sectors in Textile Industry

\begin{tabular}{|c|c|c|c|c|c|c|}
\hline Description & CGI & SIB & SIOWN & SIDIS & SIRPT & SIREM \\
\hline \multirow{2}{*}{ Sector 1} & -2.85 & $2.37^{\dagger}$ & $73.76^{* * *}$ & $-3.90^{*}$ & $-83.64^{\dagger}$ & -0.48 \\
\hline & 0.44 & $(1.81)$ & (3.98) & $(2.60)$ & $(1.79)$ & $(0.48)$ \\
\hline \multirow{2}{*}{ Sector 2} & -1.06 & 0.36 & $-82.44 * * *$ & $4.04 *$ & 60.59 & -0.62 \\
\hline & $(0.15)$ & $(0.29)$ & $(4.33)$ & $(2.12)$ & (1.22) & $(0.70)$ \\
\hline \multirow{2}{*}{ Sector 3} & 1.60 & -1.68 & $-74.91 * * *$ & $3.94 *$ & 77.37 & -0.75 \\
\hline & $(0.24)$ & (1.38) & (3.98) & $(2.26)$ & $(1.56)$ & $(0.87)$ \\
\hline \multirow{2}{*}{ Sector 4} & -8.90 & -1.97 & $-79.19 * * *$ & & 55.94 & -1.59 \\
\hline & (1.12) & (1.17) & (3.84) & & (1.09) & $(1.42)$ \\
\hline \multirow{2}{*}{ Sector 5} & 0.05 & $-4.54^{\dagger}$ & $-75.29^{\dagger}$ & & & -1.45 \\
\hline & $(0.00)$ & $(1.81)$ & (1.92) & - & - & $(0.74)$ \\
\hline \multirow{2}{*}{ EBITTA } & $13.72 * * *$ & $15.61 * * *$ & $15.94 * * *$ & $14.02 * * *$ & $14.05^{* * *}$ & $12.95^{* * *}$ \\
\hline & $(10.55)$ & $(15.05)$ & (13.82) & (10.88) & (12.74) & (12.86) \\
\hline \multirow{2}{*}{ TA } & 0.17 & & 0.02 & 0.13 & $0.51 * * *$ & $0.35 * *$ \\
\hline & $(0.96)$ & - & $(0.18)$ & $(0.73)$ & $(3.87)$ & $(2.61)$ \\
\hline \multirow{2}{*}{ GROW } & $-0.33^{*}$ & -0.08 & -0.03 & $-0.33^{*}$ & & -0.15 \\
\hline & (2.13) & $(0.66)$ & $(0.21)$ & (2.08) & - & $(1.25)$ \\
\hline TS & - & $\begin{array}{c}-0.45 * * * \\
(3.55)\end{array}$ & - & - & - & - \\
\hline DAR & - & $\begin{array}{c}-1.11 * * * \\
(5.83)\end{array}$ & - & - & $\begin{array}{c}-0.78 * * * \\
(4.11)\end{array}$ & - \\
\hline AGE & - & - & - & - & $\begin{array}{c}-0.02 * \\
(1.99) \\
\end{array}$ & - \\
\hline $\mathbf{R}^{2}$ & 0.2249 & 0.4435 & 0.0013 & 0.2673 & 0.4275 & 0.4483 \\
\hline Observations & 307 & 305 & 290 & 307 & 308 & 307 \\
\hline Regression & $\mathrm{FE}$ & $\mathrm{RE}$ & $\mathrm{FE}$ & $\mathrm{FE}$ & $\mathrm{RE}$ & $\mathrm{RE}$ \\
\hline
\end{tabular}

Notes: $\dagger \mathrm{p}<0.10 ; * \mathrm{p}<0.05 ; * * \mathrm{p}<0.01 ; * * * \mathrm{p}<0.001 . \mathrm{t}$ value in parentheses.

Sectors 1, 2, 3, 4 and 5 represent sub-sectors synthetic, composite, spinning, weaving and woolen respectively in the Textile Industry. VAIC (value-added intellectual coefficient) is dependent variable. CGI (corporate governance index), SIB (subindex board), SIOWN (sub-index ownership), SIDIS (sub-index disclosure), SIRPT (sub-index related party transactions) and SIREM (sub-index remuneration) are independent variables. EBITTA (earnings before interest and taxes (EBIT) divided by total assets), TA (total assets), GROW (percentage change in sales), TS (total sales), DAR (total debt to total asset ratio) and AGE (number of years from year of registration in SECP to year 2014) are the control variables. Fixed effect and random effect techniques have been applied.

The impact of CGI on intellectual capital performance in all sub-sectors is insignificant. The two sectors 1 (synthetic) and 5 (woolen) give significant results for SIB. The impact of SIOWN is significant in intellectual capital performance in all sub-sectors whereas only three sub-sectors (synthetic, composite and spinning) are significant in SIDIS. The values of sub-sectors 4 (weaving) and 5 (woolen) are omitted by the regression technique because the same values are repeated in different companies due to the incorporation of binary variables $(0$ or 1$)$ and few observations.

The impact of SIRPT on performance in sub-sector 1 (synthetic) is significant. The value of subsector 5 (woolen) is omitted due to a lack of observations. The impact of SIREM on performance is insignificant for all sub-sectors. 


\section{CONCLUSION}

The main objective of this research study is to determine the impact of a self-constructed corporate governance index developed from five sub-indices on intellectual capital performance measured through the value-added intellectual coefficient (VAIC). The data for analysis is extracted from the annual reports from 2010 to 2014 of the textile industry. An industry-focused systematic sampling technique has been used to make a reliable sample.

Two hypotheses are tested in this study. The main hypothesis is related to the corporate governance index with intellectual capital performance whereas the other is related to sub-indices of the corporate governance index. Apart from these hypotheses, the link between intellectual capital performance and individual variables of the sub-indices is also tested. Descriptive statistics, correlation matrix, and regression techniques have been applied to get the results. Sub-sectors of the textile industry are also analyzed to find out the association between intellectual capital performance and corporate governance.

The findings of this study show significant but negative impact of corporate governance index on intellectual capital performance in the textile sector. Most of the previous studies in corporate governance literature provide positive significant relationship but few studies show a negative significant impact as well such as Bebchuk et al. (2004); Ertugrul and Hegde (2009). The significant impact indicates that corporate governance plays a vital role in the performance of this sector whereas negative sign gives an indication that there are many hurdles that restrain this industry to show positive and growing situation. The energy crisis, devaluation of Pakistan rupee, political instability, lack of skilled labor, efficient management, latest technology and the noncompliance of governance practices may be the causes of negative impact on intellectual capital performance. The one reason for negative significant results of CGI may be the significant negative outcomes of its sub-indices SIRPT and SIREM.

The hypotheses related to sub-indices have given mixed results. Consistently with literature, the sub-index board has a significant positive impact on intellectual capital performance which explains that the board characteristics have an influence to boost intellectual performance in the textile sector (Abidin et al., 2009). Only two characteristics of board namely independent director and audit committee independence show a positive significant impact. It explains that independent directors and independent audit committees play a vital role in the enhancement of intellectual performance. Board of directors is responsible for the supervision of management and development of policies that provide strength to companies therefore, when independent directors are present on board, it gives an indication for board independence that runs the business in a constructive direction. The significant positive results indicate that these two governance practices are practiced in the textile sector.

When individual variables of these sub-indices are investigated, the results are also insignificant except for foreign shareholder ownership. These variables may be the one reason for insignificant results and the data and sector may be the other reasons. The results are confirmed by the study of Javaid and Saboor (2015) who targeted the manufacturing sector of Pakistan. When these subindices are examined sub-sectors wise, the outcomes indicate that the impact is significant for all sub-sectors except sub-sectors 4 and 5 in sub-index disclosure where the data was omitted due to lack of observations and recurrence of data. 
The outcomes display that sub-index related party's transactions have a significant negative impact on intellectual performance consistent with the study of Black (2005); Black et al. (2012). The information about related parties' transactions in annual reports has an influence on intellectual performance but the negative results indicate that the transactions with related parties are the hindrances in the performance of companies.

There is a negative significant impact of sub-index remuneration on intellectual performance steady with the study of Usman et al. (2015). Significant impact gives a hint about the influence of remuneration related characteristics on performance while negative results indicate a sign about the agency problems in the textile sector which meant that directors and executives are paid regardless of performance. The different environments and weak corporate governance systems in the textile sector may be the other reason for the negative impact. It also indicates that the board is not capable to formulate such contracts and policies that give the compensation to executives and directors for their performance.

Talking about the control variables, the findings suggest that operating performance (EBITTA), size (TS), leverage (DAR) and firm age have a significant impact on firm intellectual performance with a positive sign for operating performance and negative sign for other variables. The growth provides an insignificant impact in every model but without growth, the variations explained by the independent variables on the dependent variable $\left(\mathrm{R}^{2}\right)$ become low. In other words, the models show good results in the presence of growth variables. The total asset (size) shows both significant and insignificant impact in different models. The outcomes of control variables were supported by past studies (Black, 2005; Black et al., 2012).

\section{REFERENCES}

Ab Razak, N. H., Ahmad, R., \& Aliahmed, H. (2008). Government ownership and performance: An analysis of listed companies in Malaysia. Corporate Ownership and Control, 6(2), 434-442.

Abdoli, M., Panahi, H., \& Rahimiyan, F. (2013). The effect of corporate governance factors on the improvement of intellectual capital. Journal of Social Issues and Humanities, 1(7), 7480.

Abidin, Z. Z., Kamal, N. M., \& Jusoff, K. (2009). Board structure and corporate performance in Malaysia. International Journal of Economics and Finance, 1(1), 150.

Al-Musalli, M. A. K., \& Ismail, K. N. I. K. (2012). Corporate governance, bank specific characteristics, banking industry characteristics, and Intellectual Capital (IC) performance of banks in Arab Gulf Cooperation Council (GCC) countries. Asian Academy of Management Journal of Accounting and Finance, 8(Supp. 1), 115-135.

Balasubramanian, B. N., Black, B. S., \& Khanna, V. S. (2008). Firm-level corporate governance in emerging markets: A case study of India. ECGI-Law Working Paper, 119(2009), 8-11.

Bebchuk, L. A., Cohen, A., \& Ferrell, A. (2004). What Matters in Corporate Governance?," Working Paper, Harvard Law School and NBER.

Bharathi, K. G. (2010). The intellectual capital performance of banking sector in pakistan. Pakistan Journal of Commerce \& Social Sciences, 4(1). 
Black, B. S. (2005). How corporate governance affects firm value: Evidence on channels from Korea. School of Law Law and Econ Research Paper Number 09-23 University of Texas School of Law Law and Economics Working Paper No. 51 University of Texas, McCombs School of Business.

Black, B. S., De Carvalho, A. G., \& Gorga, É. (2012). What matters and for which firms for corporate governance in emerging markets? Evidence from Brazil (and other BRIC countries). Journal of Corporate Finance, 18(4), 934-952.

Black, B. S., Jang, H., \& Kim, W. (2003). Does corporate governance affect firm value?: Evidence from korea.

Brick, I. E., Palmon, O., \& Wald, J. K. (2006). CEO compensation, director compensation, and firm performance: Evidence of cronyism? Journal of Corporate Finance, 12(3), 403-423.

Cerbioni, F., \& Parbonetti, A. (2007). Exploring the effects of corporate governance on intellectual capital disclosure: an analysis of European biotechnology companies. European Accounting Review, 16(4), 791-826.

Cheung, Y. L., Thomas Connelly, J., Limpaphayom, P., \& Zhou, L. (2007). Do investors really value corporate governance? Evidence from the Hong Kong market. Journal of International Financial Management \& Accounting, 18(2), 86-122.

Chiraz, D., \& Anis, J. (2013). Corporate governance and delisting risk of French IPO firms. International Review of Management and Business Research, 2(1), 117-127.

Ertugrul, M., \& Hegde, S. (2009). Corporate governance ratings and firm performance. Financial Management, 38(1), 139-160.

Firer, S. \& Williams, S. M. (2003). Intellectual capital and traditional measures of corporate performance. Journal of Intellectual Capital, 4(3), 348-360.

Gruszczynski, M. (2006). Corporate governance and financial performance of companies in Poland. International Advances in Economic Research, 12(2), 251-259.

Gujarati, D. N. (2009). Basic econometrics: Tata McGraw-Hill Education.

Ho, C. A., \& Williams, S. M. (2003). International comparative analysis of the association between board structure and the efficiency of value added by a firm from its physical capital and intellectual capital resources. The International Journal of Accounting, 38(4), 465-491.

Hodgson, A., Lhaopadchan, S., \& Buakes, S. (2011). How informative is the Thai corporate governance index? A financial approach. International Journal of Accounting \& Information Management, $19(1)$, 53-79.

Ismail, K., \& Karem, M. A. (2011). Intellectual capital and financial performance of banks in Bahrain. Journal of Business Management and Accounting, 1(1), 63-77.

Javaid, F., \& Saboor, A. (2015). Impact of corporate governance index on firm performance: Evidence from Pakistani manufacturing sector. Journal of Public Administration and Governance, 5(2), Pages 1-21.

Keenan, J., \& Aggestam, M. (2001). Corporate governance and intellectual capital: Some conceptualisations. Corporate Governance: An International Review, 9(4), 259-275.

Korent, D., Đunđek, I., \& Čalopa, M. K. (2014). Corporate governance practices and firm performance measured by Croatian Corporate Governance Index (CCGI $\left.{ }^{\circledR}\right)$. Economic Research-Ekonomska Istraživanja, 27(1), 221-231.

Makki, M. A. M, \& Lodhi, S. A. (2013). Impact of corporate governance on financial performance. Pakistan Journal of Social Sciences (PJSS), 33(2), 265-280.

Makki, M. A. M., \& Lodhi, S. A. (2014). Impact of corporate governance on intellectual capital efficiency and financial performance. Pakistan Journal of Commerce and Social Sciences, 8(2), 305-330. 
Ministry of Finance. (2015a). Federal budget 2015-16. Retrieved April 2016, from http://www.finance.gov.pk/fb_2015_16.html

Ministry of Finance. (2015b). Pakistan Economic Survey 2014-15. Retrieved April 2016, from http://www.finance.gov.pk/survey_1415.html

Page, M. (2009). Corporate governance and corporate performance: UK FTSE 350 companies: The Institute of Chartered Accountants of Scotland.

Pulic, A. (1998). Measuring the performance of intellectual potential in knowledge economy.

Pulic, A. (2004). Intellectual capital-does it create or destroy value? Measuring business excellence, 8(1), 62-68.

Renders, A., Gaeremynck, A., \& Sercu, P. (2010). Corporate-governance ratings and company performance: A cross-european study. Corporate Governance: An International Review, $18(2), 87-106$.

Sabir, H. M., Arshad, A., Sardar, S., \& Latif, B. (2014). VAIC and Firm Performance: Banking Sector of Pakistan. Paper presented at the Information and Knowledge Management.

Shih, K. H., Chang, C. J., \& Lin, B. (2010). Assessing knowledge creation and intellectual capital in banking industry. Journal of Intellectual Capital, 11(1), 74-89.

Taliyang, S. M., \& Jusop, M. (2011). Intellectual capital disclosure and corporate governance structure: Evidence in Malaysia. International Journal of Business and Management, 6(12), 109-117.

Tariq, Y. B., \& Butt, S. A. (2008). Impact of corporate governance practices on financial performance: empirical evidence from Pakistan. Paper presented at the Paper presented $\&$ published in conference proceedings at 8th Annual Hawaii International Conference on Business.

Ulum, I., Ghozali, I., \& Purwanto, A. (2014). Intellectual capital performance of Indonesian banking sector: A modified VAIC (M-VAIC) perspective. Asian Journal of Finance \& Accounting, 6(2), 103-123.

Usman, M., Akhter, W., \& Akhtar, A. (2015). Role of board and firm performance in determination of CEO compensation: Evidence from Islamic Republic of Pakistan. Pakistan Journal of Commerce and Social Sciences, 9(2), 641-657.

Varshney, P., Kaul, V. K., \& Vasal, V. (2012). Corporate governance index and firm performance: empirical evidence from India. Available at SSRN 2103462. 